\title{
Ombilin Basin as Inverted Oblique Rift in Barisan Mountains, Sumatra: Considerations on Subsidence Mechanisms and Fault Development
}

\author{
Aldo Febriansyah Putra*1, Chalid Idham Abdullah², Dardji Noeradi \\ ${ }^{1}$ Department of Geology, Chulalongkorn University, Thailand \\ 254 Phayathai Rd, Pathum Wan, Pathum Wan District, Bangkok 10330, Thailand \\ ${ }^{2}$ Geodynamics and Sedimentology Research Group, Institut Teknologi Bandung, Indonesia \\ Ganesa St. No.10, Bandung, Jawa Barat 40132, Indonesia \\ *E-mail: aldofputra@gmail.com
}

Article received: 8 July 2021, revised: 30 August 2021, accepted: 30 August 2021

DOI: 10.51835/iagij.2021.1.2.32

\begin{abstract}
Ombilin Basin is an NW-SE inverted oblique rift that is currently being part of the Barisan Mountains in western-Central Sumatra. Regarding its current position, Ombilin Basin can be one of the windows to see the evolution of the Barisan Mountains since the Paleogene. Two schools of thought, namely rift basin and pull-apart basin have been established to explain the evolution of the Ombilin Basin. This paper aims to present another perspective on the evolution of the Ombilin Basin based on subsidence mechanisms and fault development. This study integrated remote sensing and subsurface interpretations. Remote sensing interpretation took the role to delineate surface fault lineaments using a digital elevation model, while subsurface interpretation dealt with log and seismic interpretations, subsidence analysis, and palinspatic reconstruction. Fault lineaments derived both from remote sensing and seismic interpretations were combined to construct the structural framework of the basin. Subsidence analysis generated geohistory and back-stripped tectonic subsidence charts. Palinspatic reconstruction illustrated structural configurations through time. This study figured out that Ombilin Basin went through faultcontrolled subsidence in Middle Eocene - Late Oligocene and thermal subsidence in Early Miocene - Late Pliocene. Each subsidence mechanism was terminated by an uplift. Subsidence mechanisms in Ombilin Basin represented the criteria of rift basin in terms of amount and rate of tectonic subsidence, duration of subsidence, and contribution of thermal subsidence. On the other hand, fault development captures extensional and strike-slip components during rifting and the development of flower structures during inversion of the basin. Oblique rifting operates when the dominant extensional component works together with the strike-slip component. Therefore, subsidence mechanisms and fault development are in agreement to regard Ombilin Basin as an inverted oblique rift.
\end{abstract}

Keywords: Ombilin Basin, oblique rift, inversion

\section{INTRODUCTION}

Ombilin Basin is an NW-SE inverted oblique rift that is currently being part of the Barisan Mountains in western-Central Sumatra. Regarding its current position, Ombilin Basin can be one of the windows to see the evolution of the Barisan Mountains since the Paleogene. The evolution of the basin has been studied for several decades and generated two schools of thought: rift basin [14] and pull-apart basin [5-8]. The schools of thought would be the basis of this study to present another perspective on the basin evolution.

The schools of thought have different perspectives in seeing Ombilin Basin (Figure 1). Rift basin school of thought builds the idea based on the tectonostratigraphic framework and basin geometry [1-4]. Otherwise, the pullapart basin school of thought considers Sumatran Fault as a major structure responsible for Ombilin Basin formation 
$[1,6,7]$. This study provides another Ombilin Basin based on subsidence perspective in constructing the evolution of the mechanisms and fault development.
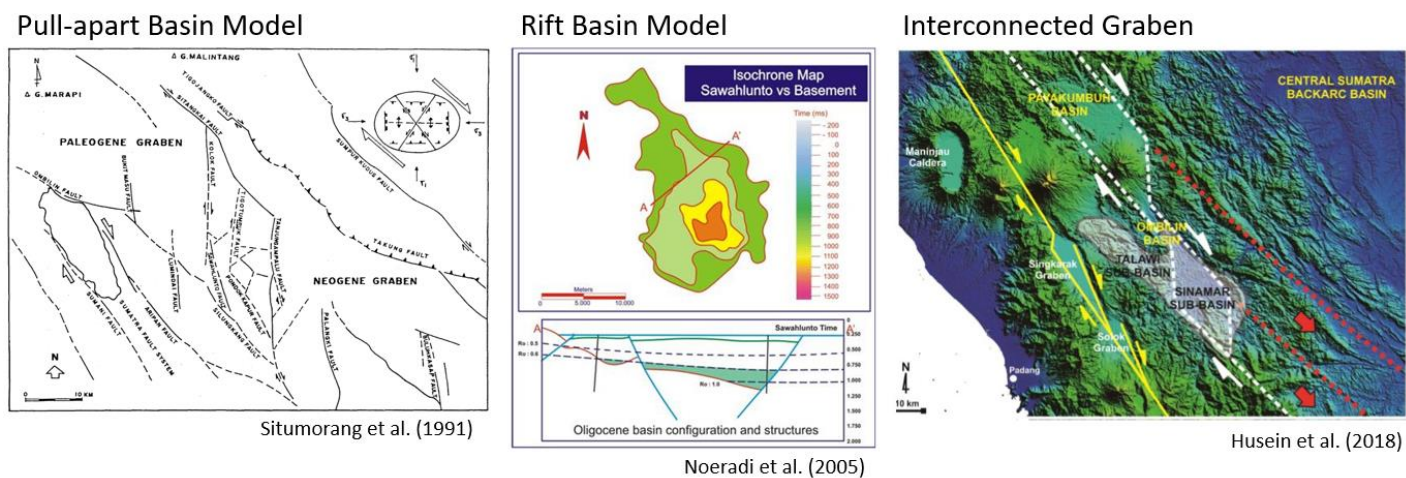

Figure 1. Schools of thought of Ombilin Basin formation.

The evolution of the Ombilin Basin was studied by integrating remote sensing and subsurface interpretations. Remote sensing interpretation deals with understanding surface structural features and fault lineaments. In the meantime, subsurface interpretation encompasses seismic interpretation and subsidence analysis. The seismic interpretation would be the basis for palinspatic reconstruction. On the other hand, subsidence analysis produced geohistory and backstripped tectonic subsidence charts to illustrate the basin evolution. The study area is illustrated in Figure 2 and 3.

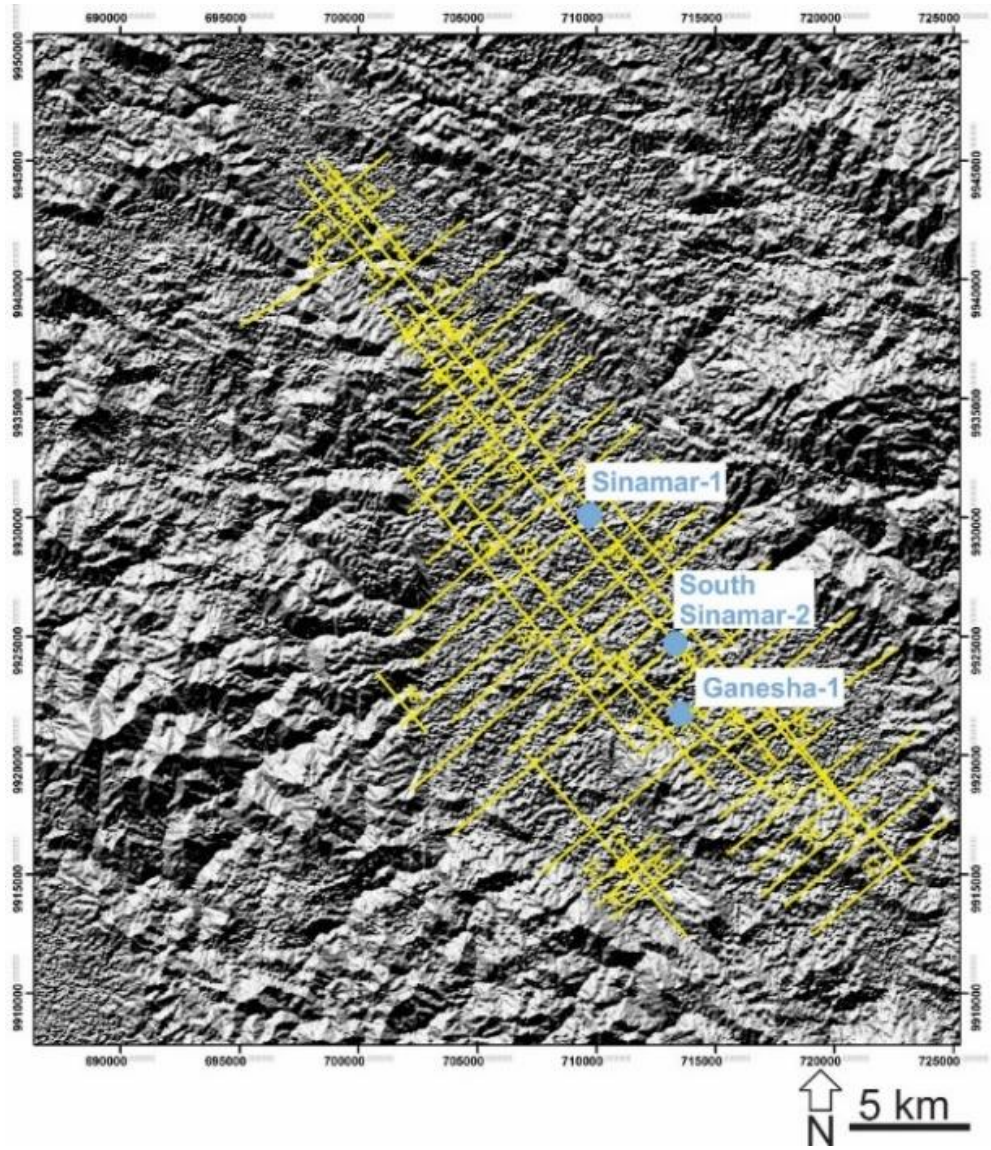

Figure 2. Study area with 2D seismic coverage and the wells. 


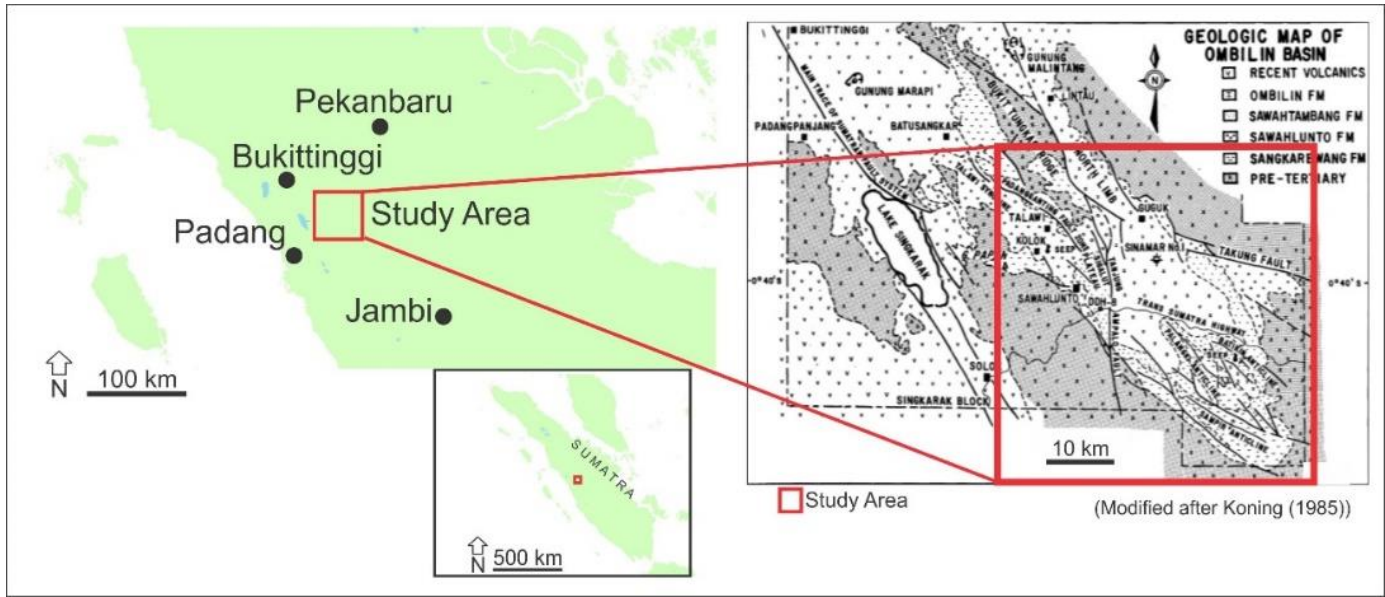

Figure 3. Location map of study area.

\section{REGIONAL GEOLOGY}

The tectonic evolution of Sumatra has started since the Late Paleozoic. IndochinaEast Malaya Block collided with South China Block in Late Carboniferous (Barber and Crow, 2009; (Figure 4). Another collision occurred in the Late Permian between Indochina-East Malaya Block with Sibumasu Block, closing the Paleo-Thetys Sea. After the closing of the Paleo-Thetys Sea, West Sumatra Block moved along strike-slip fault regarded as Medial Sumatra Tectonic Zone and finally juxtaposed with Sibumasu Block in Middle Triassic [12]. Tectonic evolution during Jurassic to Cretaceous was characterized by the Meso-Tethys Sea, the formation of Woyla and Incertus Arcs, and the movement of those two arcs northwards and the opening of the Ceno-Tethys Sea [13]. Woyla Arc finally arrived in Sumatra and collided with other tectonic blocks in the Late Cretaceous [12]. It can be underlined from the reviews above that Sumatra has been part of convergent margin since Late Carboniferous to Recent.

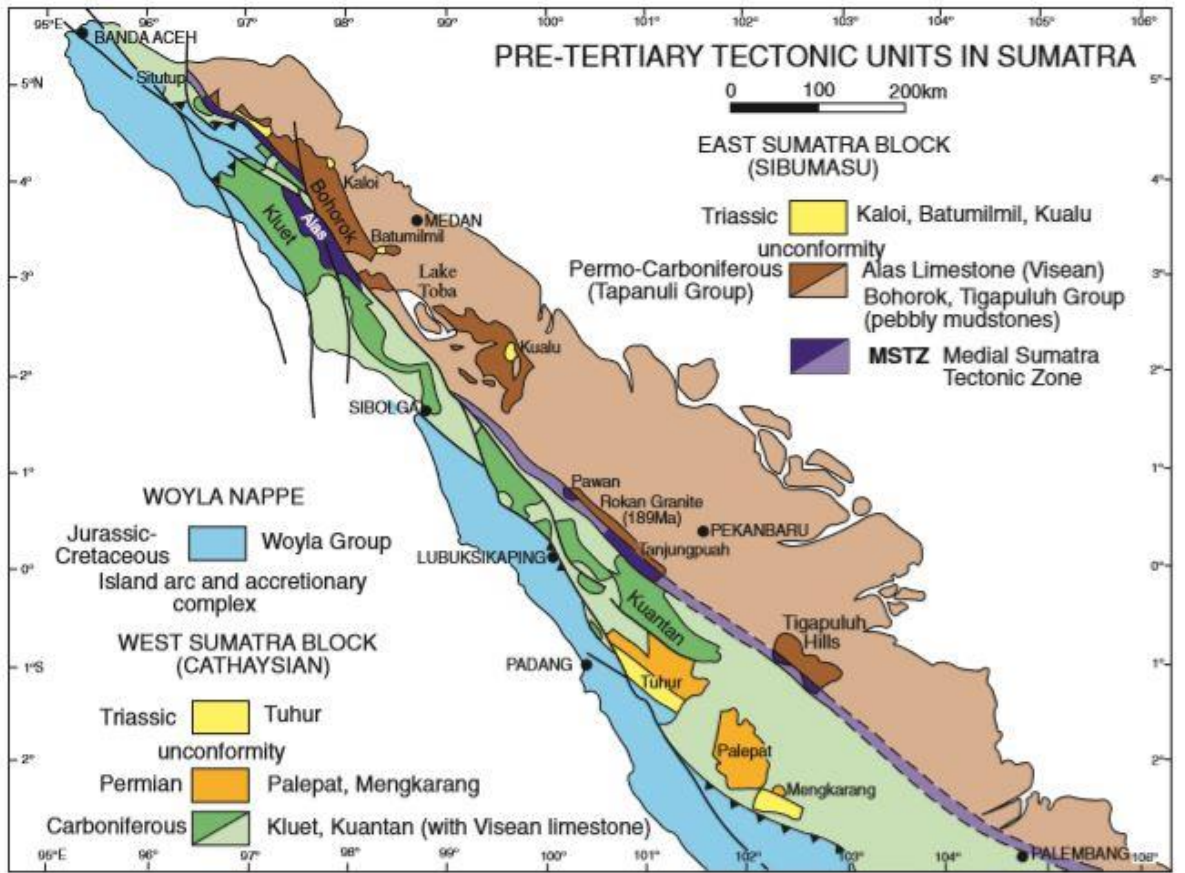

Figure 4. Tectonic blocks of Sumatra [12]. 
Ombilin Basin is a part of the Barisan Mountains (Figure 5) and is aligned parallel with the mountain range. Based on surface geology (Figure 6), Ombilin Basin has two important trends, NW-SE and N-S. Noticeable NW-SE features include the Takung Fault in the northern part of the basin and Palangki Anticline in the south. Takung Fault served as a major structure in the Ombilin Basin, as illustrated by [14] (Figure 7). N-S trend is represented by Tanjung Ampalo Fault and its escarpment. Moreover, Ombilin Basin can be divided as Talawi Sub-basin in the west and Sinamar Sub-basin in the east. The model of Ombilin Basin with Tanjung Ampalo Fault drew as an intra-basinal structure between the two sub-basins [14] (Figure 7).

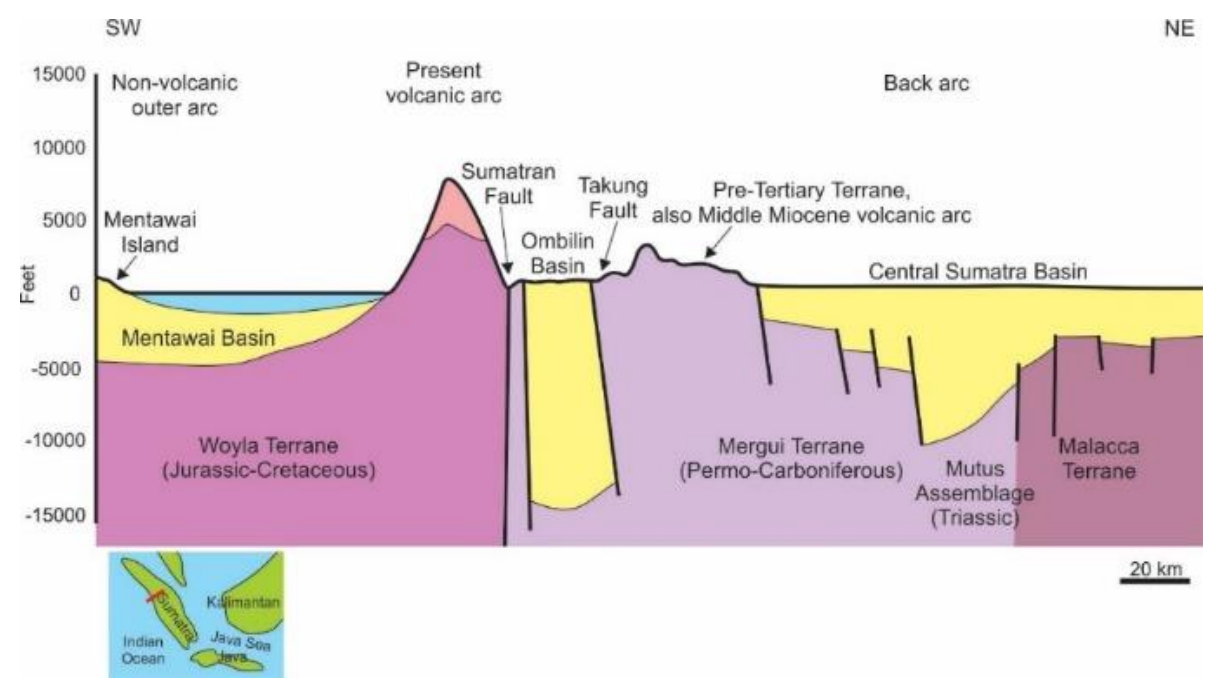

Figure 5. Tectonic setting of Ombilin Basin, modified after [18].

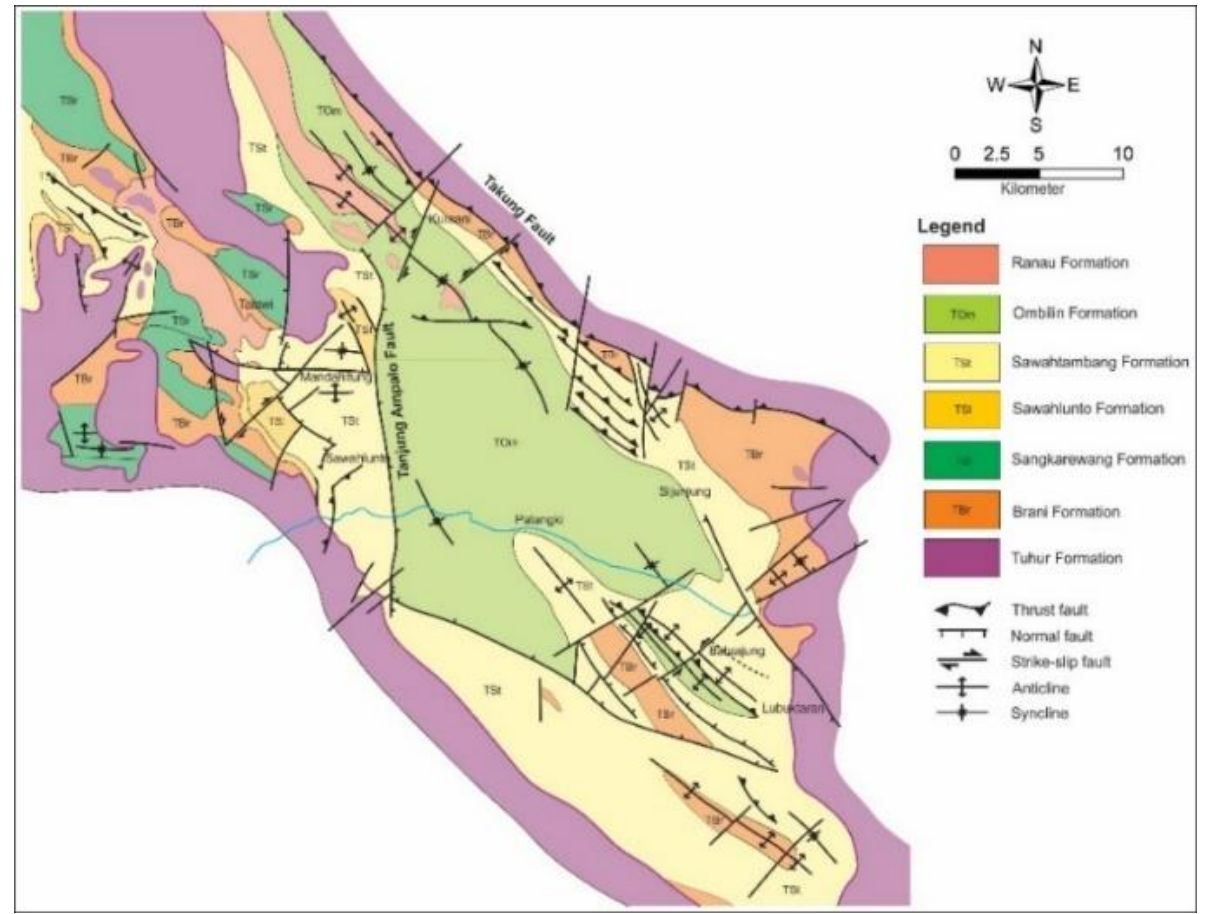

Figure 6. Geologic map of Ombilin Basin, modified after [1]. 


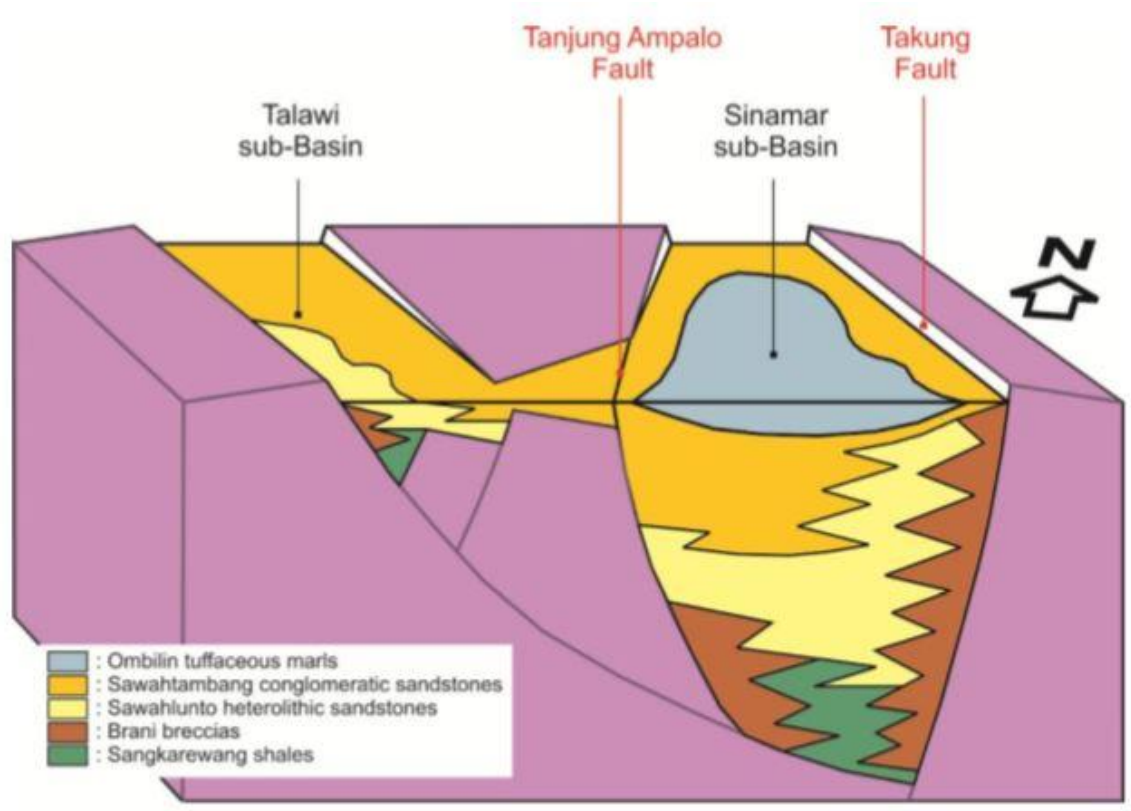

Figure 7. Schematic model of Ombilin Basin [14].

The evolution of the Ombilin Basin started in Paleogene. Initial sedimentation was marked by terrestrial deposit of Sangkarewang and Brani Formation. Sangkarewang Formation is recognized by its lacustrine deposit of laminated shale and intercalation of sandstone [1,3,7]. Varve layers of this formation reported in the [14]. Lacustrine turbidite facies described as contorted mudstones and interbedded sandstone with ripup clasts in this formation [3]. On the other hand, Brani Formation can be recognized by its polymict conglomerates. Brani Formation regarded as alluvial fan [1]. In terms of basin stratigraphy, Brani Formation considered as basin margin facies and Sangkarewang Formation as deeper basin facies [3].

Sedimentation in the Ombilin Basin was followed by deposition of Sawahlunto and Sawahtambang Formations in Paleogene. Sawahlunto Formation is recognized as meandering stream facies $[1,3,14]$ and Sawahtambang Formation as braided stream facies [1,14]. Sawahlunto Formation is characterized by the presence of coal, while Sawahtambang Formation can be recognized by its thick, massive sequence of cross-bedded sandstones and conglomeratic sandstones.

Neogene sedimentation in the Ombilin Basin is characterized by marine facies of the Ombilin Formation. Ombilin Formation has heterolithic shale, carbonaceous and calcareous shale, and thin intercalation of glauconitic sandstone [1,14]. Local uplift toward the end of Oligocene manifested by erosional surface at Palangki [1]. Therefore, the stratigraphic relationship between Ombilin Formation and younger formations might be locally unconformable. The sedimentary record in Ombilin Basin ends in the Early Miocene because younger successions had been eroded.

\section{DATA AND METHOD}

The study area approximately covers about $1600 \mathrm{~km}^{2}$ (Figure 3). This study utilized both remote sensing and subsurface data. Remote sensing interpretation used Advanced Spaceborne Thermal Emission and Reflection Radiometer Global Digital Elevation Model (ASTER GDEM). ASTER GDEM is a product of METI and NASA. Subsurface data include 
a 2D reflection seismic database and three wells.

Remote sensing interpretation was intended to generate a shaded relief model and to delineate surface fault lineaments. The shaded relief model was generated by artificial illumination from four directions. The area was illuminated from west, northwest, north, and northeast with the angle of light was $30^{\circ}$. Shaded relief models generated from four illumination directions were combined to produce the final shaded relief model. The result of the modeling is presented in Figure 3. The final shaded relief model would be the basis for interpreting surface fault lineaments.

The subsurface interpretation made use of a 2D reflection seismic database and wells. 2D seismic reflection database and the wells would be tied by vertical seismic profiling data. Data coming from the wells included wireline logs, biostratigraphic reports, and geochemical reports. Wireline $\operatorname{logs}$ and biostratigraphic reports were used to create chronostratigraphic units. Chronostratigraphic units would enable seismic interpretation to generate horizons based on ages and would assist subsidence analysis to have less uncertainties in assigning absolute ages. Since seismic interpretation generated horizons based on ages, moreover, palinspatic reconstruction would display structural configuration at the assigned ages.

Subsidence analysis was performed in Sinamar-1 Well because it penetrated the deep part of the basin. Subsidence analysis considered paleobathymetric correction, decompaction, and back-stripping. Paleobathymetric correction and age would be helped by biostratigraphic reports and the biostratigraphic correlation chart of [9].
Besides chronostratigraphic units, wireline logs were used to generate porosity-to-depth curves for the basis of decompaction. On the other hand, vitrinite reflectance data from geochemical reports were used for erosion estimation. The method used in erosion estimation referred to [10]. Going further, subsidence analysis performed back-stripping to generate tectonic subsidence by removing sediment load. Back-stripped used the equation from [11] and removal of sediment loads is compensated by Airy-type response.

Fault development was constructed by remote sensing and subsurface interpretations and with palinspatic reconstruction. Palinspatic reconstruction helped to illustrate structural configurations through time. Structural configurations in Eocene, Oligocene, and Intra-Early Miocene were illustrated. Insights derived from palinspatic reconstruction were synthesized with the overall structural framework of the basin.

\section{RESULT AND DISCUSSION}

The structural geology of the Ombilin Basin was interpreted based on remote sensing and reflection seismic data. Fault lineaments observed from remote sensing and seismic interpretations were integrated. Ombilin Basin has three structural trends (Figure 8). They are NW-SE, N-S, and NE-SW. NW-SE surface fault lineaments were represented as Takung, Palangki, Koto Baru, and Talawi Faults. Another feature of the NW-SE trend is the anticlinal ridge of Palangki in the southern part of the basin. Tanjung Ampalo Fault forms an escarpment of the N-S trend (Figure 8). Subsurface structural trends are NW-SE and NE-SW (Figure 8). 

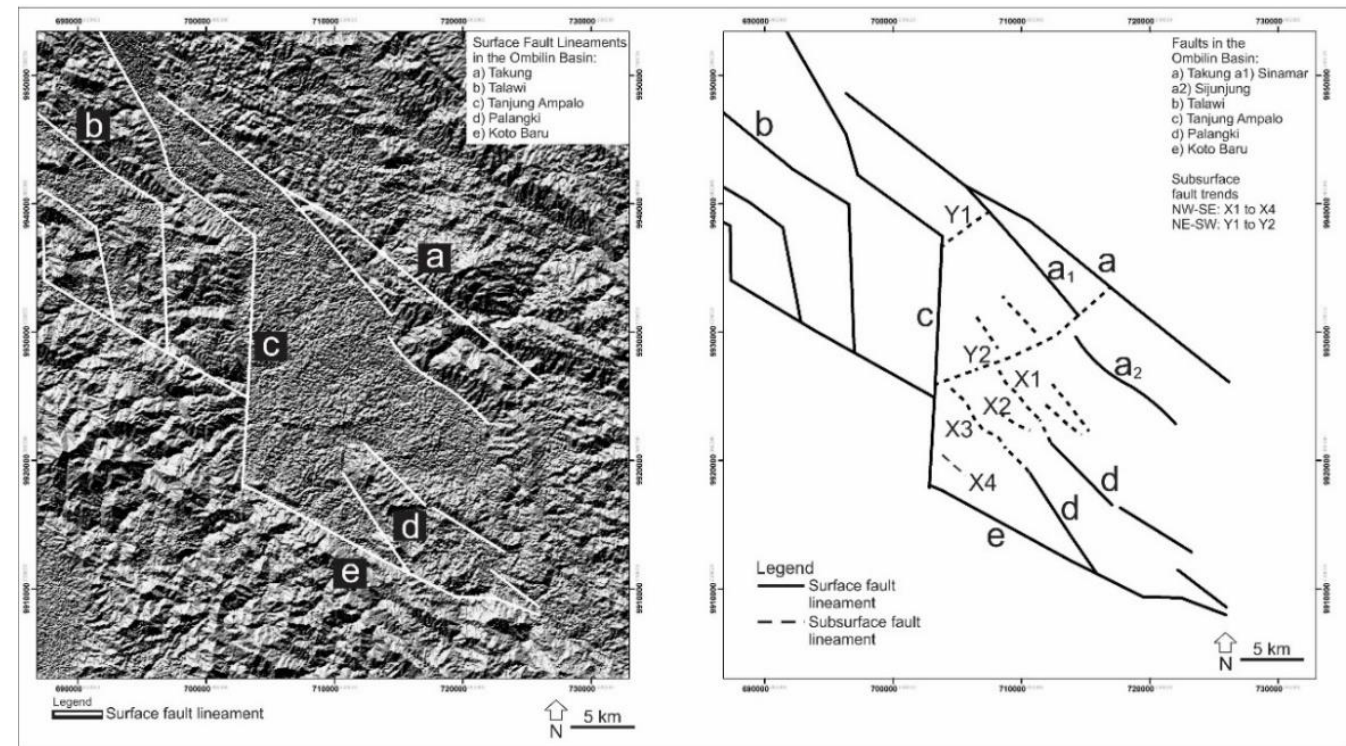

Figure 8. Fault lineaments of the Ombilin Basin.

Seismic interpretations of SW-NE sections show Ombilin Basin as inverted halfgraben tilting to the northeast. Figure 9 shows the interpretation of Sinamar Anticline as a positive flower structure. As a comparison, Figure 10 shows the structural configuration constructed by Sijunjung and X1 - X4 Faults, and Palangki Anticline. Sinamar, Sijunjung, and Palangki Anticlines are positive flower structures, trending in the NW-SE direction. Both sections also show that Eocene and
Oligocene Units thicken towards Sinamar and Sijunjung Faults. In Figure 9, Intra-Early Miocene Unit shows a relatively parallel reflector, while the unit shows thickening towards Sijunjung and X1 Faults in Figure 10. On the other hand, Sinamar and Sijunjung Faults dip in opposite directions, suggesting that they are different subsidiaries of the Takung Fault. Sinamar Fault acts as a synthetic subsidiary of Takung Fault, while Sijunjung Fault becomes antithetic one.

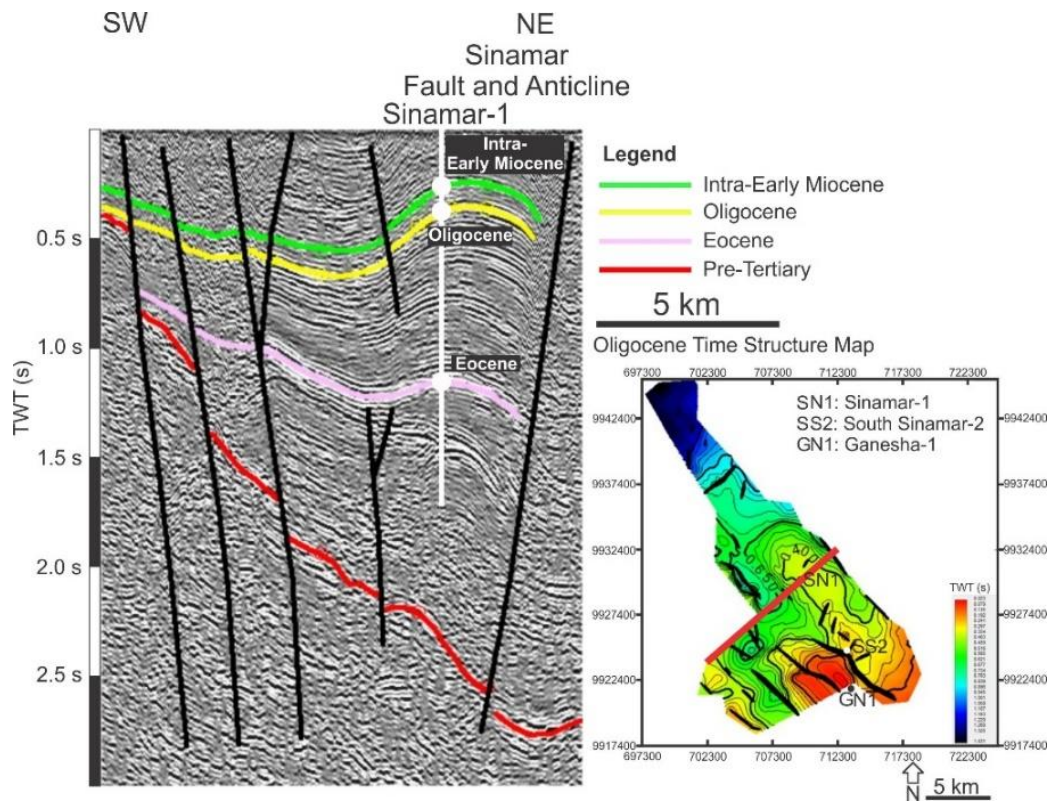

Figure 9. Seismic interpretation of Sinamar Fault and Anticline. 


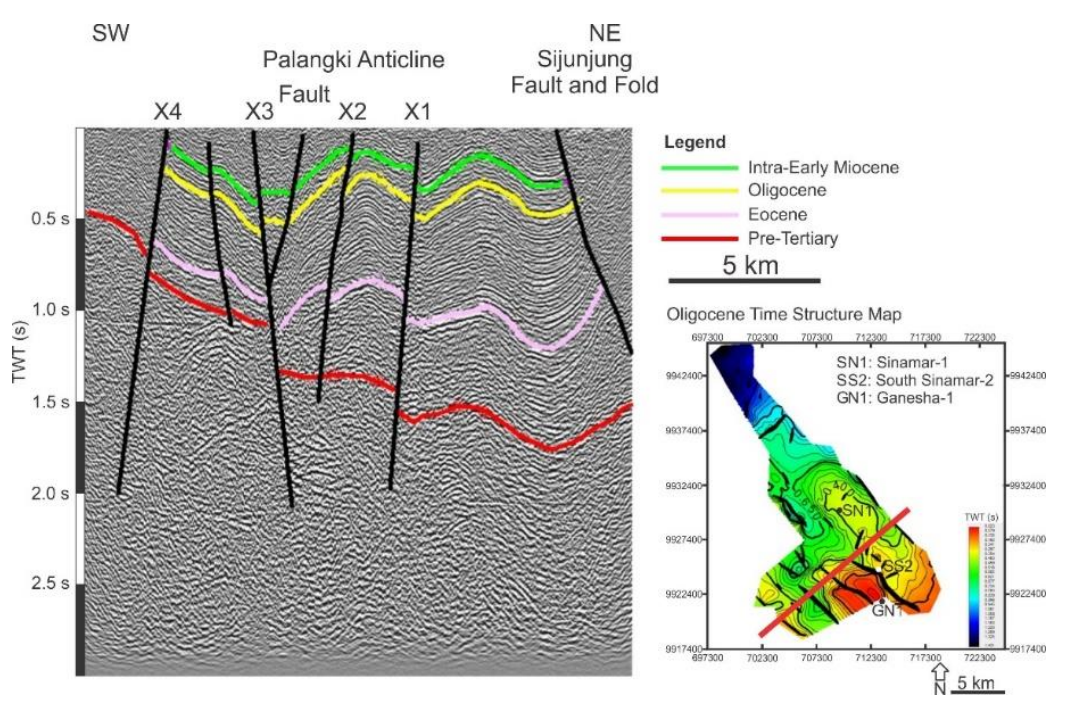

Figure 10. Seismic interpretation of Sijunjung Fault-Fold, Palangki Anticline, and X1 - X4 Faults.

Seismic interpretation on NE-SW section (Figure 11) runs along Sinamar Anticline. Together with other faults, Y1 and Y2 Faults outline the deepest part of the Ombilin Basin. Y1 and Y2 Faults also display positive flower structures. On the other hand, Eocene and
Oligocene Units show thickness variation, therefore, their deposition was contemporaneous with fault activity. IntraEarly Miocene Unit appears to have a parallel reflector.
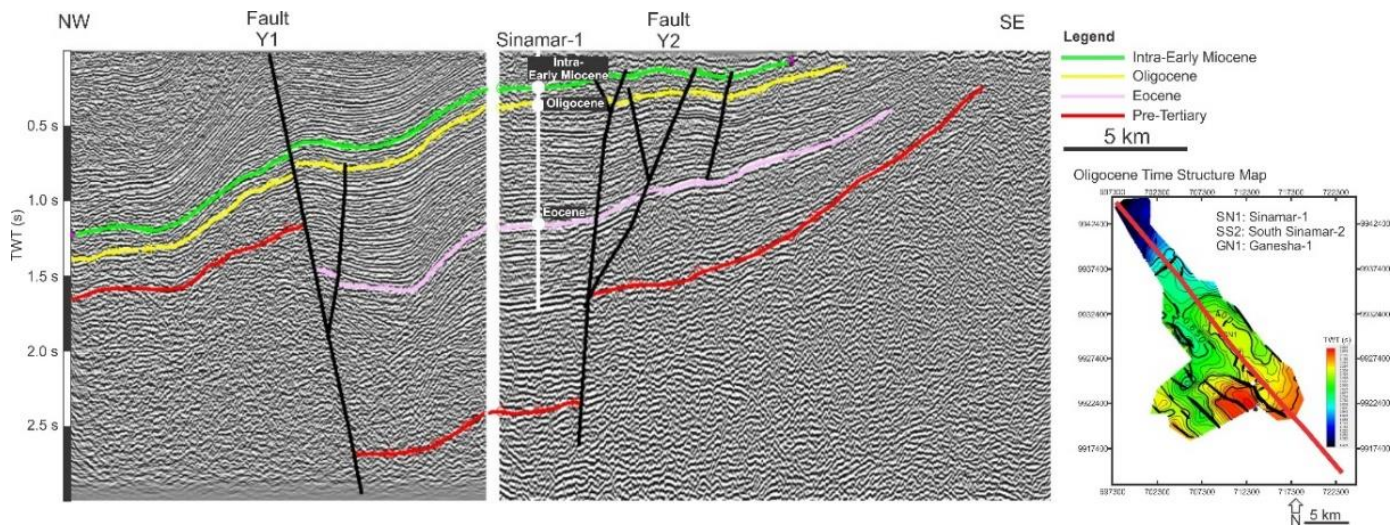

Figure 11. Seismic interpretation of Sinamar Anticline and Y1 - Y2 Faults.

Furthermore, subsidence analysis aimed to illustrate basin evolution through geohistory and back-stripped tectonic subsidence charts. Geohistory chart incorporated sediment thickness, age, paleo-bathymetry, and reconstruction of eroded thickness in depicting basin evolution. Back-stripped tectonic subsidence, meanwhile, gives the estimate of tectonic contribution in both subsidence and uplift during basin evolution. Both charts help understand basin evolution along with knowledge derived from seismic interpretation.

Geohistory chart of Ombilin Basin (Figure 12) illustrated the evolution of Ombilin Basin from Middle Eocene to Recent. Rifting began in Middle Eocene and continued until the Late Oligocene. As expressed in seismic interpretation (Figure 9-11), fault activity had been contemporaneous with sedimentation 
during Middle Eocene to Late Oligocene. Ombilin Basin recorded terrestrial environment from Middle Eocene to Late Oligocene. Transient uplift and erosion in Late Oligocene removed about 585.5 meters of sediment thickness, as estimated from vitrinite reflectance data. Following the transient uplift, subsidence and deposition occurred during the Early Miocene to Late Pliocene. Marine deposition occurred during the Early Miocene to, interpretatively, Late Pliocene. Deposition in the Ombilin Basin came to an end in Late Pliocene, as de the peak of Barisan Orogeny occurred in that time range [15]. Estimation based on vitrinite reflectance data showed erosion of about 1151 meters sediment thickness. Considering the estimation of eroded thickness in both uplifts, Ombilin Basin reached a maximum depth of burial in Late Oligocene at approximately 3954 meters and about 5279 meters in Late Pliocene.

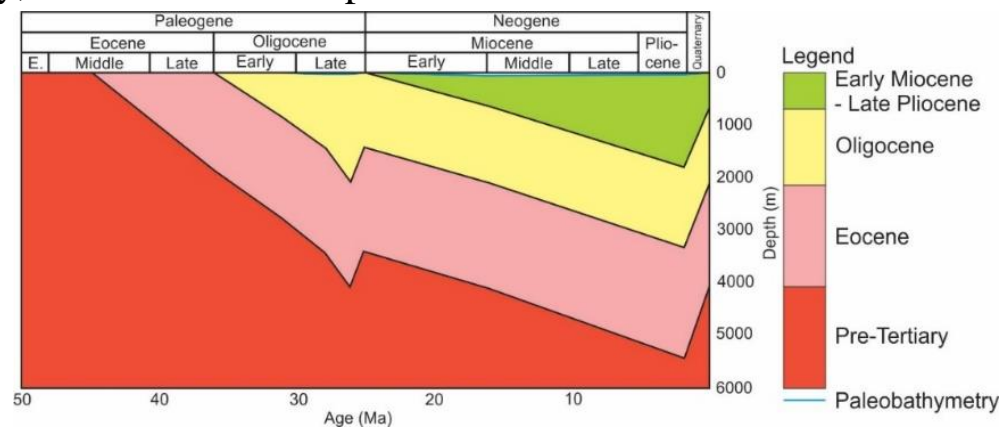

Figure 12. Geohistory chart of Ombilin Basin.

Back-stripping helped the reconstruction of basin evolution in terms of interpreting subsidence mechanisms. With the knowledge from seismic interpretation, back stripped tectonic subsidence could be used to determine the phase of fault-controlled and thermal subsidence (Figure 13). Fault-controlled subsidence in the Ombilin Basin, as stated earlier, operated in Middle Eocene to Late Oligocene. Such mechanism was terminated by uplift and followed by thermal subsidence in the Early Miocene to Late Pliocene. The latest uplift of the Ombilin Basin occurred in Late Pliocene to Recent, following the rise of the Barisan Mountains.

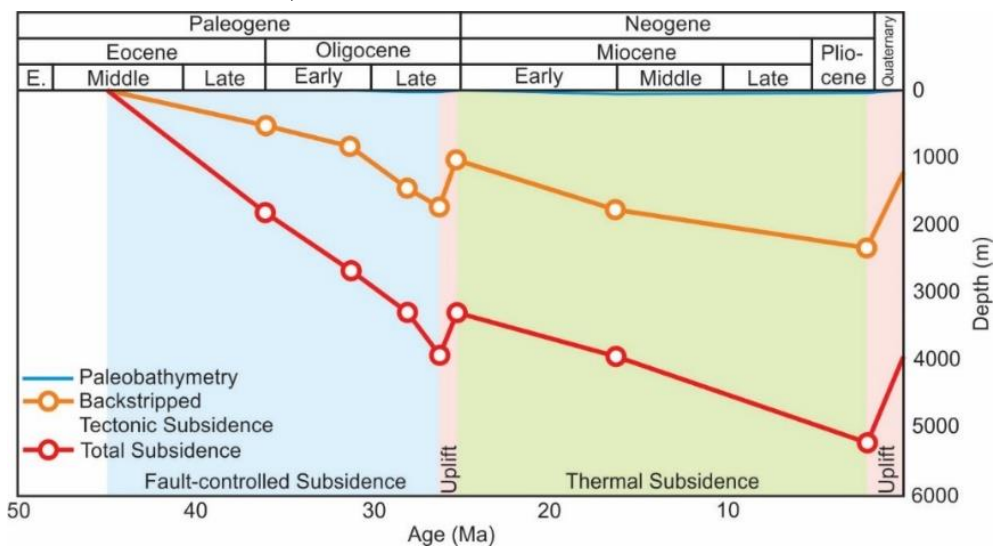

Figure 13. Backstripped tectonic subsidence chart of Ombilin Basin.

Fault-controlled subsidence showed the Oligocene (Figure 12). Subsidence in the variation of rates from Middle Eocene to Late Middle Eocene operated at the rate of about 
$0.06 \mathrm{~mm} / \mathrm{yr}$. The rate was accelerating to 0.2 $\mathrm{mm} / \mathrm{yr}$ towards the Late Oligocene, but it then slightly slowed down to $0.16 \mathrm{~mm} / \mathrm{yr}$ before the uplift. With a duration of subsidence of about 18.8 Ma, fault-controlled subsidence reached its maximum depth around 1752 meters.

Thermal subsidence had less variation in terms of rate than fault-controlled subsidence (Figure 14) but had a longer duration of subsidence. Thermal subsidence ran for about $23.2 \mathrm{Ma}$ and reached a maximum depth of about 2342 meters. On the onset of thermal subsidence, the rate was approximately 0.08 $\mathrm{mm} / \mathrm{yr}$ and decreased towards Late Pliocene to be around $0.04 \mathrm{~mm} / \mathrm{yr}$. Decreasing rate of subsidence during Early Miocene - Late Pliocene might become evidence of thermal decay.

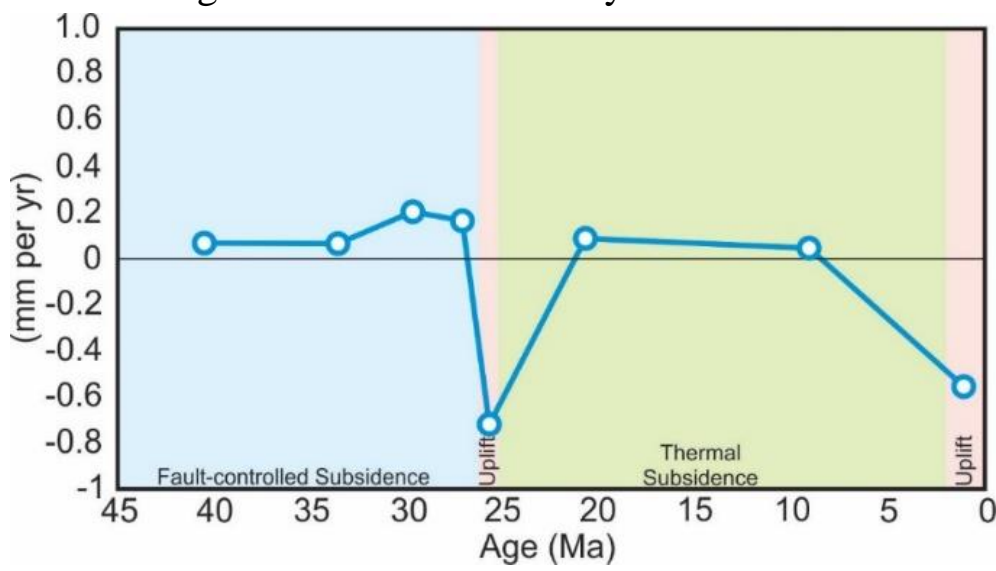

Figure 14. Tectonic subsidence and uplift rates of Ombilin Basin.

As shown in Figure 15, a cross-plot This cross-plot gives insight of Ombilin Basin between the duration of subsidence and back- evolution compared to other basins worldwide. stripped tectonic subsidence rate was created Further concern on Ombilin Basin subsidence to distinguish basin types [15]. In this cross- mechanisms will be provided in the discussion plot, Ombilin Basin is regarded as a rift basin. part.

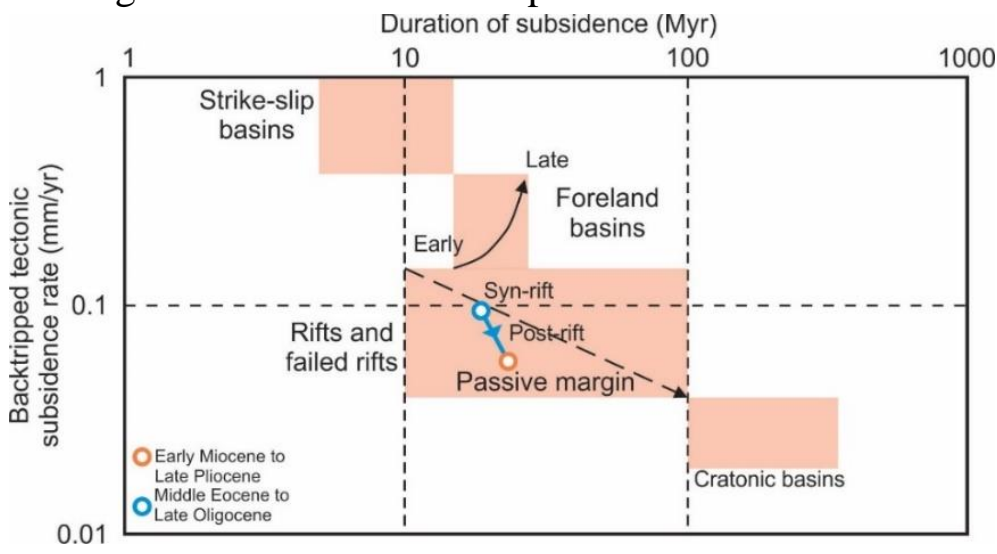

Figure 15. Ombilin Basin is regarded as rift basin in this chart [16].

As previously elaborated in subsidence analysis, Middle Eocene to Late Oligocene was marked by fault-controlled subsidence. Palinspatic reconstruction goes in agreement with that geologic event and shows that structural configurations during Middle Eocene to Late Oligocene are dominated by normal faulting (Figure 16). Oligocene structural configuration reveals the contribution of strike-slip components during 
rifting. Folding and faulting of Eocene Unit during Oligocene deposition indicates strikeslip component during rifting. As manifested in Figure 16b, Eocene Unit shows an increasingly tighter fold towards Sijunjung Fault than the overlying Oligocene Unit. This
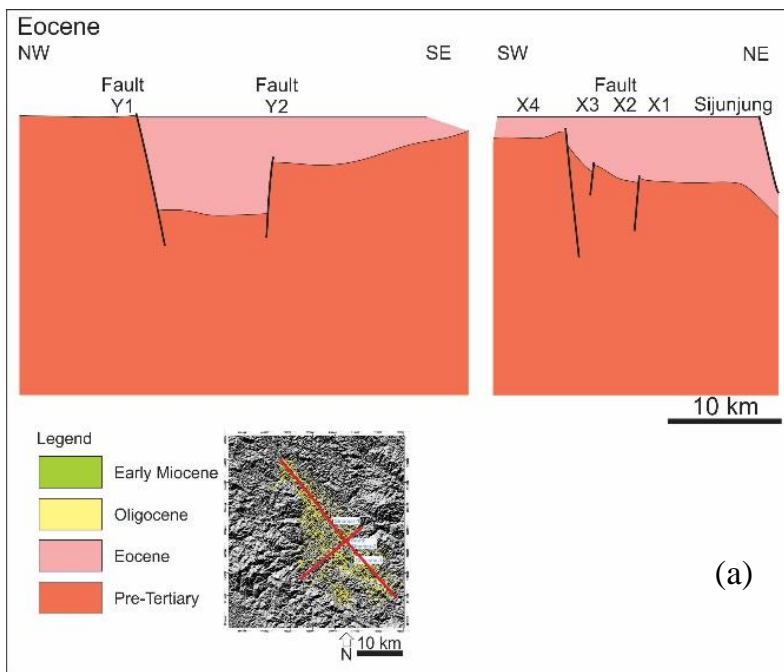

(a)

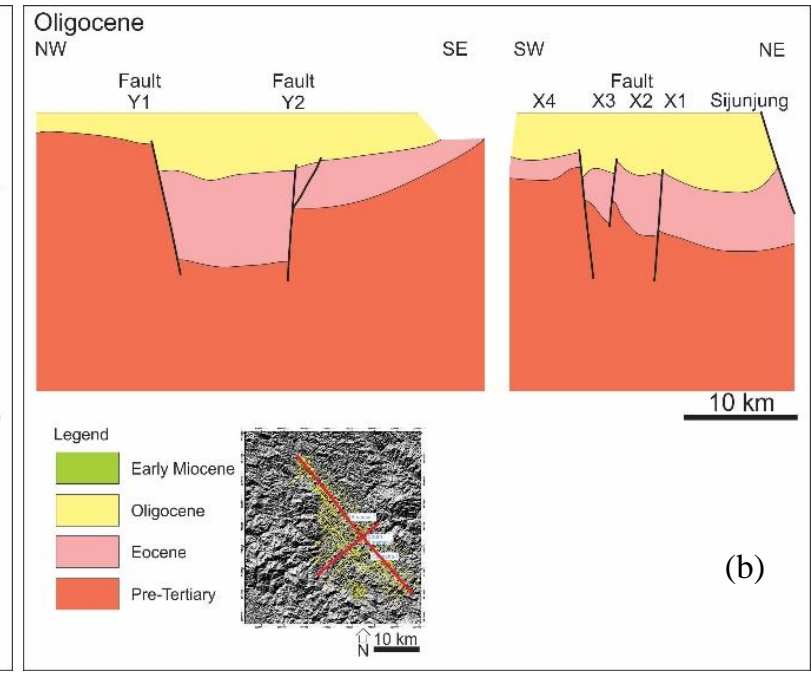

Figure 16. Structural configuration in (a) Eocene; (b) Oligocene.

Ombilin Basin experienced uplift after deposition of Oligocene Unit. The uplift is illustrated as inversion of faults in the Ombilin Basin. As drawn in Figure 17a, NW-SE faults were reactivated to be reverse faults, while NE-SW faults were reactivated as strike-slip faults. This uplift made deposition of IntraEarly Miocene Unit to have varying thickness. means that folding of the Eocene Unit occurred at the same time with deposition of the Oligocene Unit. In addition, strike-slip component was also a consequence to enable all fault trends to facilitate Ombilin Basin rifting.

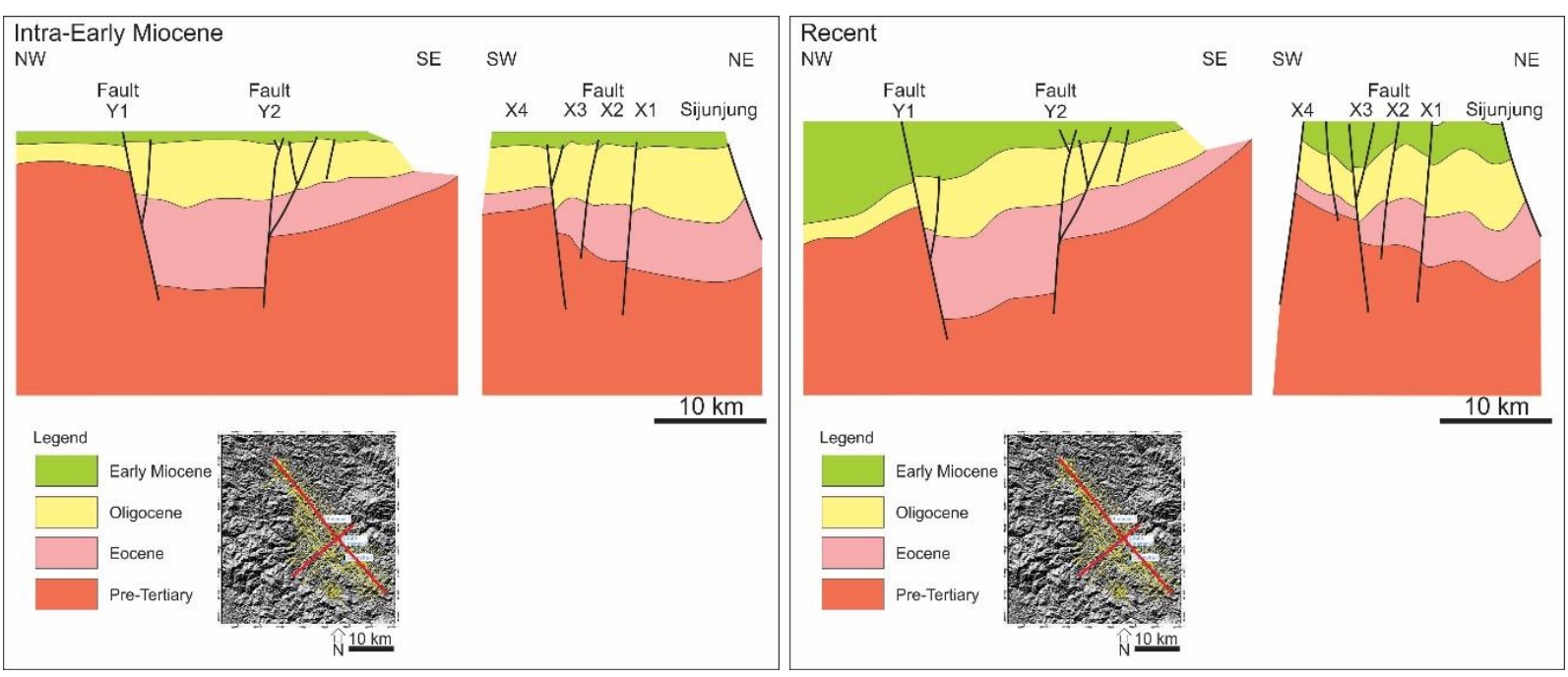

Figure 17. Structural configuration in (a) Intra-Early Miocene; (b) Recent. 
Ombilin Basin has NW-SE Takung Fault as major structure of the basin. Takung Fault significantly governed subsidence and inversion. Sinamar and Sijunjung Faults are its subsidiaries and can be regarded as synthetic and antithetic structures, respectively. Other NW-SE faults can be categorized as secondary structures of the Ombilin Basin. On the other hand, N-S and NE-SW faults developed contemporaneously with Takung Fault because sedimentary successions thickened towards the three faults in Middle Eocene Late Oligocene. N-S and NE-SW faults can be regarded to be transverse faults of the basin.

Subsidence mechanisms in the Ombilin Basin occurred as fault-controlled subsidence (Middle Eocene - Late Oligocene) and thermal subsidence (Early Miocene - Late Pliocene). Each subsidence mechanism was terminated by uplift. Fault-controlled subsidence was also expressed in seismic interpretation and illustrated in Eocene - Oligocene structural configuration. Oligocene Unit could be distributed over N-S and NE-SW faults might be caused by Takung Fault significant contribution to subsidence. As mentioned earlier, rate of fault-controlled subsidence was accelerating from Middle Eocene to Late Oligocene. Subsidence caused by Takung Fault might outpace other faults to enable wide distribution of Oligocene Unit. Moreover, the onset of thermal subsidence in Ombilin Basin was studied by [17]. The study revealed that apatite fission track analysis in western Talawi Sub-basin suggests that thermal cooling operated in $\sim 23-15 \mathrm{Ma}$ (Early - Middle Miocene) [17]. The time range of thermal subsidence fits with backstripped tectonic subsidence of this study.

In addition, thermal history of Talawi Sub-basin was conducted and estimated the total subsidence. The maximum depth of burial reached by Talawi Sub-basin could be no more than 2200 meters [17]. Considerations put in this estimation were surface temperature of $30^{\circ} \mathrm{C}$ and geothermal gradient of $30^{\circ} \mathrm{C}$ per kilometer, as recorded in Sinamar-1 Well [18]. Taking this case as comparison, Sinamar Subbasin had been the deepest part of Ombilin Basin throughout its history.

Back-stripped tectonic subsidence is comparable between basins. Comparison of Ombilin Basin with other areas in the world is important to determine basin type based on subsidence mechanisms. Comparison with other basins was conducted by using compilations and criteria [16,18]. Regarding the criteria for intracratonic rift, the tectonic subsidence is commonly less than $2 \mathrm{~km}$ with slow, long-lived subsidence of typically more than $200 \mathrm{Ma}$ [19]. Thermal subsidence is significant in intracratonic basin, and its origin as thermal decay is based on the geometry of tectonic subsidence curve resembling seafloor subsidence. In addition, strike-slip basins have greater tectonic subsidence of $2-4 \mathrm{~km}$. Duration of subsidence is short, commonly less than $10 \mathrm{Ma}$. Since heat is strongly dissipated during fault-controlled subsidence, strike-slip basins have insignificant thermal subsidence. Ombilin Basin does not fulfill slow, long-lived subsidence of intracratonic basin but its duration of subsidence is far longer than the common strike-slip basin. Strike-slip component during oblique rifting may be an explanation of such tectonic subsidence duration. By considering the criteria created by [19], cross-plot by [16], and the study results, Ombilin Basin should be regarded as oblique rift basin.

The idea of Ombilin Basin as inverted oblique rift emerged from the synthesis of subsidence mechanisms and fault development. Subsidence mechanisms express 
that Ombilin Basin evolved as a rift basin. Fault development helps to visualize the changes in structural configurations and depicts strike-slip component during rifting in Middle Eocene - Late Oligocene and development of flower structures during inversion in Late Oligocene and Late Pliocene. Therefore, subsidence mechanisms and fault development are in agreement to regard Ombilin Basin as an inverted oblique rift.

\section{CONCLUSIONS}

Ombilin Basin is an inverted oblique rift that is currently being part of the Barisan Mountains, Sumatra, based on subsidence mechanisms and fault development. Subsidence mechanisms in Ombilin Basin can be divided as fault-controlled subsidence (Middle Eocene-Late Oligocene) and thermal subsidence (Early Miocene - Late Pliocene). Each subsidence mechanism was terminated by uplift. Ombilin Basin fits the criteria as a rift basin in terms of duration of subsidence, amount of tectonic subsidence, and the evidence of thermal subsidence. Fault development depicts the strike-slip component during rifting and the development of positive flower structures during inversion.

\section{ACKNOWLEDGEMENT}

This paper is a part of first author's master's thesis at Institut Teknologi Bandung. We would like to thank geoscientists and management of PT. Rizki Bukit Barisan Energi for subsurface data access and discussions. We would like to thank Brahmantyo K. Gunawan, Dr. Yarra Sutadiwiria, and Salahuddin Husein, $\mathrm{PhD}$ for the discussions.

\section{REFERENCES}

1. Koesoemadinata, R.P.; Matasak, T.; Stratigraphy and sedimentation Ombilin Basin Central Sumatra (West Sumatra Province), In the $10^{\text {th }}$ Annual Convention Proceeding of Indonesian Petroleum Association, 1981, p. $217-249$.

2. Howells, C.; Tertiary response to oblique subduction and indentation in Sumatra, Indonesia: New ideas for hydrocarbon exploration: Geological Society Special Publications, 1997, p. $365-374$.

3. Noeradi, D.; Djuhaeni; Simanjuntak, B.; Rift play in Ombilin Basin Outcrop, West Sumatra, In the $13^{\text {th }}$ Annual Convention Proceeding of Indonesian Petroleum Association, 2005,p. IPA05-G-160.

4. Husein, S.; Barianto, D. H., Novian, M. I., Putra, A. F., Saputra, R., Rusdiyantara, M. A., and Nugroho, W., 2018, Perspektif baru dalam evolusi Cekungan Ombilin Sumatera Barat: Proceedings Seminar Nasional Kebumian Ke-11 Universitas Gadjah Mada.

5. Koning, T.; Petroleum geology of the Ombilin Intermontane Basin, West Sumatra, In the $14^{\text {th }}$ Annual Convention Proceeding of Indonesian Petroleum Association, 1985, p. 117 - 137.

6. Situmorang, B.; Yulihanto, B.; Guntur, A.; Himawan, R.; Jacob, T.G.; Structural development of the Ombilin Basin West Sumatra, In the $12^{\text {th }}$ Annual Convention Proceeding of Indonesian Petroleum Association,1991, p. 1 - 15.

7. Zaim, Y.; Habrianta, L.; Abdullah, C.I.; Aswan; Rizal, Y.; Basuki, N.I.; Sitorus, F.E.; Depositional history and petroleum potential of Ombilin Basin, West Sumatra - Indonesia based on surface geological data, AAPG International Convention and Exhibition, Singapore, 2012.

8. Habrianta, L.; Matthew, G.; Fakhrurozi, F.; Auliansyah, D.; Andhika, I.P.; A semi-regional play analysis of the Ombilin Basin to understand the tectono-stratigraphic framework and identification of potential exploration opportunities, In the $42^{\text {nd }}$ Annual Convention Proceeding of Indonesian Petroleum Association, 2018, p. IPA18-482-G.

9. Van Gorsel, J.T.; Biostratigraphy in Indonesia: Methods, pitfalls, and new directions, In the $17^{\text {th }}$ Annual Convention Proceeding of Indonesian Petroleum Association, 1988, p. 275 - 300.

10. Dow, W.G.; Kerogen studies and geological interpretations, Journal of Geochemical Exploration, 1977, 7, p. $79-99$.

11. Steckler, M.S.; Watts, A.B.; Subsidence of the Atlantic-type continental margin off New York, Earth and Planetary Science Letters, 1978, 41, p. $1-13$.

12. Barber, A. J.; Crow, M.J.; Structure of Sumatra and its implications for the tectonic assembly of 
Southeast Asia and the destruction of Paleotethys, Island Arc, 2009, 18, p. 3 - 20.

13. Hall, R.; Late Jurassic - Cenozoic reconstructions of the Indonesian region and the Indian Ocean, Tectonophysics, 2012, p. $1-41$.

14. Husein, S.; Barianto, D.H.; Novian, M.I.; Putra, A.F.; Saputra, R.; Rusdiyantara, M.A.; and Nugroho, W.; Perspektif baru dalam evolusi Cekungan Ombilin Sumatera Barat, In the Proceeding of Seminar Nasional Kebumian ke-11 Universitas Gadjah Mada, 2018.

15. De Smet, MEM.; Barber, AJ. Tertiary Stratigraphy. Geological Society, London, Memoirs. 2005, 31(1), 86-97.
16. Allen, P.A.; Allen, J.R.; Basin Analysis: Principles and Application to Petroleum Play Assessment,2013, $3^{\text {rd }}$ ed., Wiley-Blackwell, West Sussex, 619 p.

17. Moss, S. J.; Carter, A.; Thermal histories of Tertiary sediments in western central Sumatra, Indonesia, Journal of Southeast Asian Earth Sciences, 1996, 14, p. $351-371$.

18. Koning, T.; Petroleum geology of the Ombilin Intermontane Basin, West Sumatra, , In the $14^{\text {th }}$ Annual Convention Proceeding of Indonesian Petroleum Association, 1985, p. 117 - 137.

19. Xie, X.; Heller, P.L.; Plate tectonics and basin subsidence history, GSA Bulletin, 2009, 121, p. 55 -64 . 